\title{
SISTEM KLASIFIKASI BERITA DARING FAKTOR KEJAHATAN PENYALAHGUNAAN NARKOTIKA BERBASIS ALGORITMA NAIVE BAYES
}

\author{
Oki Arifin \\ Program Studi Teknologi Informasi \\ Fakultas Ilmu Komputer \\ Universitas Amikom Yogyakarta \\ Email : okiarifin@amikom.ac.id
}

\begin{abstract}
ABSTRAK
Tingginya tingkat penggunaan situs berita memungkinkan penyebaran berita yang lebih cepat, luas, aktual, dan ramah lingkungan. Kasus-kasus narkotika merupakan artikel yang banyak ditemui di media berita daring. Dari berita daring tersebut di kelompokkan berdasarkan faktor kejahatan penyalahgunaan narkotika berasal dari individu, lingkungan dan narkoba. Dengan demikian, perlu dikembangkan sebuah sistem klasifikasi yang diharapkan dapat membantu pihak kepolisian dan pihak terkait dalam mengetahui faktor penyebab kejahatan penyalahgunaan narkotika yang peningkatan kasusnya sudah semakin memprihatinkan di Indonesia. Text mining processing merupakan salah satu domain penelitian pada web mining yang bertujuan untuk menggali informasi dari kumpulan data teks yang jumlahnya sangat besar. Penelitian ini akan mengembangkan sebuah sistem dengan menggunakan teknik klasifikasi Nä̈ve Bayes (NB). Pendekatan ini merupakan pendekatan mengacu pada teorema Bayes yang merupakan prinsip peluang statistika untuk mengkombinasikan pengetahuan sebelumnya dengan pengetahuan baru. Hasil penelitian ini adalah sebuah sistem untuk mengklasifikasi berita daring faktor kejahatan penyalahgunaan narkotika yang dapat diimplementasikan dengan menggunakan algoritma Naive Bayes. Pengujian sistem menggunakan confusion matrix dengan tingkat performansi dengan data uji 225 di dapatkan nilai recall $75,8 \%$, precision $97,7 \%$, dan accuracy 96,4\%. Maka sistem klasifikasi menggunakan algoritma Naive Bayes mempunyai tingkat akurasi yang baik karena tingkat akurasinya lebih dari 50\%.
\end{abstract}

Kata Kunci: Klasifikasi, Text Mining, Naive Bayes, Confusion Matrix, Narkotika

\begin{abstract}
The high level of using news sites enables faster, widespread, actual, and environmentally-friendly news spread. Narcotics cases are articles that are often found in the online news. From the online news is grouped based on factors of crime misuse narcotics from an individual, environmental, and the narcotics. Thus, it is necessary to develop a classification system that is expected to assist the police and related parties in
\end{abstract}


knowing the factors causing narcotic misuse crimes which increase the case has been increasingly apprehensive in Indonesia. Text mining processing is one of the research domains in web mining that aims to extract information from a huge amount of text data. This research will develop a system using Naïve Bayes (NB) classification technique. This approach is an approximation to Bayes's theorem which is the principle of statistical odds to combine previous knowledge with new knowledge. The result of this research is a system to classify online news of crime misuse narcotics factor which can be implemented by using a Naive Bayes algorithm. System test using confusion matrix with performance level with test data 225 got 75,8\% recall value, precision 97,7\%, and accuracy 96,4\%. So the classification system using the Naive Bayes algorithm has a good accuracy level because of the accuracy of more than $50 \%$.

Keywords: Classification, Text Mining, Naive Bayes, Confusion Matrix, Narkotic

\section{PENDAHULUAN}

Perkembangan kasus kejahatan penyalahgunaan narkotika di Indonesia sangat mengkhawatirkan dalam beberapa kurun waktu terakhir ini menunjukkan tingkat kenaikan. Hal ini dibuktikan dengan perkembangan modus peredaran narkoba yang melibatkan anak-anak, remaja maupun mahasiswa sebagai pengguna maupun sebagai pengedar narkoba. Data di Badan Narkotika Nasional Republik Indonesia (BNN) menyebutkan bahwa sedikitnya ada 138.475 kasus penyalahgunaan zat- zat terlarang yang terjadi di Indonesia dalam kurun waktu 5 tahun terakhir, terhitung mulai tahun 2007-2011. Sedangkan selama 2011 sendiri telah tercatat sebanyak 29.526 kasus yang terjadi. Dan yang lebih mencengangkan, sebanyak 117.147 dari total 189.294 penyalahguna zat-zat terlarang adalah siswa SMA. Ironis memang mengetahui bahwa generasi muda yang seharusnya menjadi tulang punggung penerus bangsa malah menjadi $61,9 \%$ atau lebih dari separuh jumlah penyalahguna zat-zat terlarang. Zat-zat terlarang yang dimaksud mengacu pada NAPZA adalah Narkotika, Psikotropika dan Zat Adiktif lainnya (Nurlila \& Fua, 2017).

Perkembangan teknologi di bidang informasi dan komunikasi khususnya internet membawa pengaruh besar pada pola kehidupan masyarakat. Menurut halaman web Kementrian Komunikasi dan Informatika menyebutkan jumlah pengguna internet Indonesia pada tahun 2017 mencapai 112 juta pengguna. 
Indonesia menduduki posisi ke-6 seluruh dunia untuk peringkat pengguna internet. Semakin banyak kemunculan situs berita daring menjadi salah satu faktor yang menjadikan tingkat jumlah pengguna internet yang tinggi. Situs berita daring merupakan salah satu sumber berita yang dewasa ini banyak digunakan. Menurut Jati Prabowo menyebutkan bahwa situs berita daring www.viva.co.id berada di peringkat nomor satu untuk situs yang paling dikunjungi di Asia Tenggara. Situs berita www.kompas.com dan www.kapanlagi.com juga menduduki posisi jajaran top ten peringkat di Asia Tenggara (Prabowo, 2015).

Tingginya tingkat penggunaan situs berita memungkinkan penyebaran berita yang lebih cepat, luas, aktual, dan ramah lingkungan. Kasus-kasus narkoba merupakan artikel yang banyak ditemui di media berita daring. Artikel berita daring yang terus bertambah banyak dengan cepat merupakan sumber data yang dapat diolah agar didapat informasi maupun pengetahuan yang bermanfaat yang masih tersimpan di dalamnya. Dalam hal ini misalkan pada kasus narkoba, dapat diambil informasi mengenai penyebab kasus narkoba yang sekarang menjamur dari kumpulan artikel berita terkait kasus narkoba. Pendekatan text mining processing atau proses penggalian data dalam web dapat digunakan untuk mengekstraksi informasi yang ada di dalam berita daring (Wahyunita, 2016).

Web mining adalah aplikasi teknik data mining untuk melakukan ekstrak pengetahuan dari data web, dokumen web, penghubung (hyperlink) antara penggunaan dokumen website. Web mining dapat dibagi menjadi tiga kategori sesuai data yang mau di gali yaitu web content mining, web structuring mining, dan web usage mining. Web content mining merupakan penggalian terhadap isi yang terdapat halaman web. Kemudian web structuring mining merupakan penggalian untuk mencari model yang berkaitan dengan struktur hubungan inter dan intra halaman web. Sedangkan web usage mining merupakan penggalian terhadap pola penggunaan dari data (Vidya \& Banumathy, 2015).

Data yang berasal dari internet merupakan data yang berjenis tidak terstruktur. Data tidak terstruktur memerlukan pengolahan terlebih dahulu sebelum dilakukan proses lebih lanjut (Malarvizhi \& Saraswathi, 2013). Banyak 
metode yang dapat digunakan untuk mengolah data-data yang ada di dalam halaman web. Salah satunya adalah dengan pra pemrosesan atau pre-processing. Data hasil dari pre-processing dapat dianalisa dengan menggunakan berbagai macam metode antara lain Nä̈ve Bayes, Support Vector Machine, Bayesian Belief Network dan metode yang lain untuk mendapatkan klasifikasi yang diinginkan dari suatu artikel berita. Untuk proses klasifikasi dalam text mining bisa menggunakan metode klasifikasi atau supervised learning. Klasifikasi adalah proses pengidentifikasian obyek ke dalam sebuah kategori, kelas atau kelompok berdasarkan prosedur, definisi dan karakteristik yang telah ditentukan sebelumnya (Muhamad et al., 2017).

Penelitian yang mengangkat topik tentang klasifikasi dan penerapan algoritma nä̈ve bayes sudah banyak dilakukan sebelumnya. Beberapa penelitian tentang klasifikasi dokumen teks menggunakan metode text mining processing diantaranya: Penelitian yang dilakukan oleh Darujati mengembangkan aplikasi untuk klasifikasi berita teks bahasa Indonesia yang bersumber pada beberapa situs web dengan menggunakan Naive Bayes Classifier (NBC). Fokus penelitian terhadap teknik pengujian dengan berbagai macam inputan data. Penelitian menghasilkan akurasi sebesar $87 \%$ dengan data latih sebanyak 100 artikel berita (Darujati, Narotama, \& Darujati, 2016). Selanjutnya Almanie melakukan penelitian tentang decision tree classifier dan naïve bayes classifier. Fokus penelitian ini untuk menemukan hotspot kriminal spasial dan temporal. Menganalisis dataset untuk Denver, CO dan Los Angeles, CA dan membandingkan antara dua dataset melalui analisis statistik, serta didukung oleh beberapa grafik. Kemudian, menjelaskan bagaimana melakukan algoritma apriori untuk menghasilkan pola yang sering terjadi untuk hotspot kriminal. Selain itu, decision tree classifier dan nä̈ve bayes clssifier digunakan untuk memprediksi jenis kejahatan potensial. Hasil penelitian ini dapat digunakan untuk meningkatkan kesadaran masyarakat mengenai lokasi berbahaya dan membantu lembaga untuk memprediksi kejahatan di masa depan di lokasi tertentu dalam waktu tertentu (Almanie, Mirza, \& Lor, 2015). 
Dari penelitian terkait bahwa algoritma Nä̈ve Bayes sangat cocok digunakan untuk klasifikasi, karena sederhana dan memiliki akurasi yang tinggi. Pada penelitian ini akan mengembangkan sebuah sistem dengan menggunakan teknik klasifikasi Naive Bayes. Oleh karena itu, dalam penelitian ini diharapkan dapat membangun sebuah sistem yang dapat digunakan untuk melakukan analisa dan mengklasifikasikan faktor penyebab kasus penyalahgunaan narkotika. Hasil output dari sistem ini diharapkan dapat membantu pihak kepolisian dan pihak terkait dalam mengetahui faktor penyebab kejahatan penyalahgunaan narkotika yang peningkatan kasusnya sudah semakin memprihatinkan di Indonesia.

\section{METODE PENELITIAN}

\section{Naïve Bayes}

Naïve Bayes Clasifier atau disebut juga dengan Bayesian Classification merupakan metode pengklasifikasian statistik yang didasarkan pada teorema bayes yang dapat digunakan untuk memprediksi probabilitas keanggotaan suatu kelas (Muhamad et al., 2017). Nä̈ve Bayes Classifier pada penelitian ini digunakan untuk mengklasifikasikan dokumen teks. Pada algoritma Nä̈ve Bayes setiap dokumen dipresentasikan dengan masukan atribut "a1, a2, a3,..,an" dimana a1 adalah kata pertama dan berikutnya sampai an (kata ke-n), sedangkan V yaitu label kategori. Selanjutnya yaitu mencari nilai tertinggi dari kategori teks yang diujikan (VMAP). Persamaan VMAP yaitu sebagai berikut (Pramudita et al., 2018):

$$
V_{M A P}=\underset{v j \in V}{\operatorname{argmax}} P\left(V_{j}\right) \prod_{i} P\left(a_{i} \mid v_{j}\right)
$$

Nilai $\mathrm{P}\left(\mathrm{V}_{\mathrm{j}}\right)$ dihitung pada saat data latih dengan rumus sebagai berikut:

$$
P\left(V_{j}\right)=\frac{\mid \text { dokumen } j \mid}{\mid \text { dok.training } \mid}
$$

Dimana:

|dokumen j| adalah jumlah dokumen yang memiliki kategori j pada dokumen latih. |dok. training| adalah jumlah dokumen latih.

$$
P\left(a_{i} \mid v_{j}\right)=\frac{\left|n_{i}+1\right|}{\mid n+\text { kosa kata } \mid}
$$


Dimana:

1. $\mathrm{n}_{\mathrm{i}}$ adalah jumlah kemunculan kata $a_{i}$ pada dokumen yang berkategori $\mathrm{v}_{\mathrm{j}}$.

2. $\mathrm{n}$ adalah jumlah seluruh kata pada dokumen yang berkategori $\mathrm{V}_{\mathrm{j}}$.

3. kosakata adalah jumlah kata pada seluruh dokumen latih.

\section{Confusion Matrix}

Confusion matrix adalah sebuah tabel yang menyatakan jumlah data uji yang benar diklasifikasikan dan jumlah data uji yang salah diklasifikasikan. Contoh confusion matrix ditunjukkan pada Tabel 1.

Tabel 1. Confusion matrix

\begin{tabular}{|c|l|l|}
\hline \multirow{2}{*}{$\begin{array}{c}\text { Nilai prediksi } \\
\text { klasifikasi }\end{array}$} & \multicolumn{2}{|c|}{ Nilai sebenarnya } \\
\cline { 2 - 3 } TRUE & $\begin{array}{l}|c| \\
\text { TP (True Positive }) \\
\text { Correct Result }\end{array}$ & $\begin{array}{l}\text { FP (False Positive) Unexpected } \\
\text { result }\end{array}$ \\
\hline FALSE & $\begin{array}{l}\text { FN (False Negative }) \\
\text { Missing result }\end{array}$ & $\begin{array}{l}\text { TN (True Negative) Correct } \\
\text { absence of a result }\end{array}$ \\
\hline
\end{tabular}

Perhitungan precision, recall, dan accuracy dinyatakan dalam persamaan dibawah ini:

$$
\begin{aligned}
& \text { Precision }=\frac{T P}{T P+F P} \\
& \text { Recall }=\frac{T P}{T P+F N} \\
& \text { Accuracy }=\frac{T P+T N}{(T P+F N)+(F P+T N)}
\end{aligned}
$$

Menurut (Candradewi, 2015) komponen evaluasi dari klasifikasi didefinisikan sebagai berikut:

a. True Positive (TP) adalah jumlah klasifikasi kelas yang benar yang berhasil sistem hasilkan. Artinya kelas yang ditentukan oleh sistem sesuai dengan kelas realnya.

b. False Positive (FP) adalah jumlah hasil klasifikasi yang pada aktualnya tidak masuk dalam suatu kelas, di dalam sistem dimasukkan dalam suatu kelas.

c. False Negative (FN) adalah kesalahan klasifikasi, dimana sistem tidak berhasil memasukkan objek ke suatu kelas, padahal aktualnya objek tersebut mempunyai kelas. 
d. True Negeative (TN) adalah jumlah klasifikasi kelas yang salah yang berhasil sistem hasilkan. Artinya kelas yang ditentukan oleh sistem tidak sesuai dengan kelas realnya.

\section{Flowchart Sistem}

Tahapan secara keseluruhan metode penelitian dapat dilihat pada Gambar 1 dibawah ini.

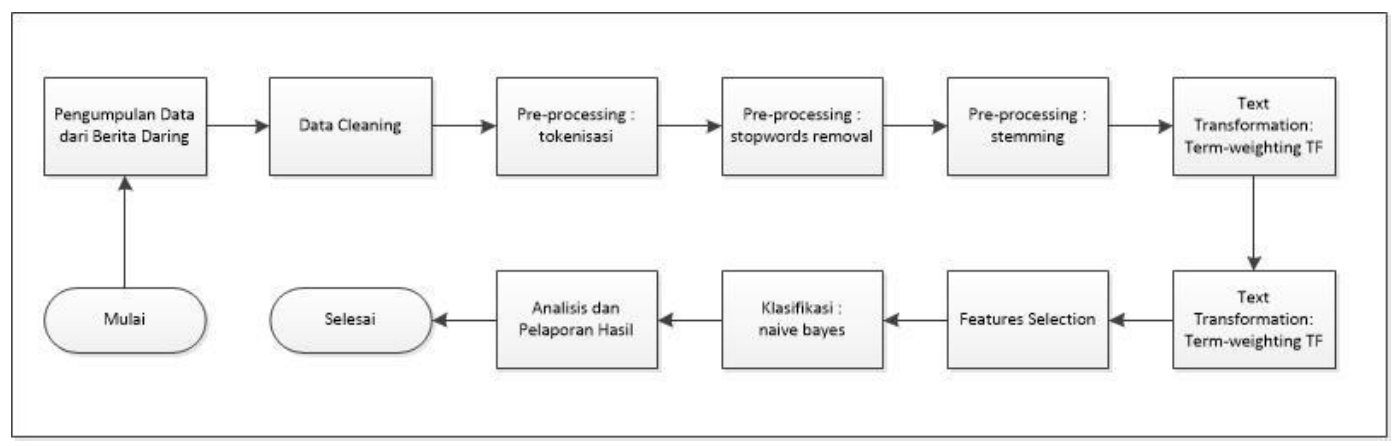

Gambar 1. Flowchart dan metode penelitian

Pada Gambar 1 untuk pengumpulan data dilakukan melalui penyaringan artikel-artikel berita daring dengan kasus penyalahangunaan narkotika dari situs berita populer yang ada di Indonesia diantaranya yaitu: detik.com, kompas.com, liputan6.com, tribunnews.com, merdeka.com, viva.co.id, okezone.com, republika.co.id, tempo.co, metrotvnews.com. Setelah memperoleh data maka selanjutnya dilakukan proses preprocessing dan kemudian data akan dibagi kedalam data latih (training) dan data uji (testing). Pada data latih akan diterapkan algoritma Naive Bayes yang merupakan algoritma yang digunakan untuk klasifikasi yang akan menghasilkan output berupa hasil klasifikasi penyebab kejahatan penyalahgunaan narkotika.

Pada penelitian ini, faktor kejahatan penyalahgunaan narkotika telah dilakukan spesifikasi menjadi tiga kategori atau kelas sebagaimana yang disebutkan dalam paper (Helviza, Mukmin, \& Amirullah, 2016). Berikut adalah faktor kejahatan penyalahgunaan narkotika:

a. Faktor Individu

Faktor individu adalah salah satu bagian dari penyebab terjadinya penyalahgunaan narkoba pada remaja. 


\section{b. Faktor Lingkungan}

Faktor lingkungan remaja menjadi bagian yang tidak bisa diabaikan dalam konteks memengaruhi remaja untuk mengonsumsi atau menyalahgunaan narkoba/NAPZA. Setidaknya, terdapat 3 lingkungan yang memengaruhi remaja menyalahgunaan narkoba, yaitu lingkunan keluarga, sekolah, dan masyarakat.

c. Faktor Narkoba

Tidak bisa di pungkiri bahwa ketersedian dan mudahnya mendapatkan narkoba dan NAPZA bagi remaja menjadi bagian yang tidak terpisahkan dari penyebab terjadinya penyalahgunaan narkoba atau NAPZA di kalangan remaja.

Dalam proses klasifikasi masing-masing kelas diberikan kata-kata kunci berdasarkan penelitian yang telah dilakukan terhadap penyebab penyalahgunaan narkotika. Adapun sebagian dari kata-kata kunci untuk masing-masing kelas faktor penyebab penyalahgunaan narkotika ditunjukkan pada Tabel 2 dibawah ini.

Tabel 2. Kata kunci kelas penyebab narkotika

\begin{tabular}{|l|l|}
\hline \multicolumn{1}{|c|}{ Kelas } & \multicolumn{1}{c|}{ Kata Kunci } \\
\hline Faktor Individu & $\begin{array}{l}\text { ajar, awas, bosan, coba, depresi, diskotik, hebat, hibur, ibu, } \\
\text { keluarga, malam, murah, narkoba, penasaran, senang, tekan, } \\
\text { tua, untung, diri, ingin, orang, minder }\end{array}$ \\
\hline Faktor Lingkungan & $\begin{array}{l}\text { bandar, berani, cafe, candu, jangkau, mudah, nikmat, sekolah, } \\
\text { kakak, ayah, ibu, diskotik, bosan, coba, broken, lokalisasi }\end{array}$ \\
\hline Faktor Narkoba & $\begin{array}{l}\text { ekstasi, ganja, kakak, ayah, nikmat, sabu, sekolah, selundup, } \\
\text { sindikat, narkoba, untung, diri }\end{array}$ \\
\hline
\end{tabular}

Data berupa artikel berita daring merupakan data yang tidak terstruktur. Sehingga membutuhkan pengolahan terlebih dahulu. Proses persiapan data berfungsi untuk mengubah artikel berita daring menjadi input yang siap untuk diproses ke tahapan berikutnya. Pada Gambar 2 memperlihatkan artikel berita daring sebelum dan sesudah proses persiapan data.

a. Pemilihan artikel berita daring

Artikel berita daring yang dipilih adalah artikel berita yang terkait dengan kasus narkotika. Artikel dipilih berdasarkan kata-kata filter yang telah ditentukan. 
b. Pembersihan data

Pembersihan data dilakukan dengan menghilangkan isi yang dianggap tidak perlu untuk diolah dan mengubah isi dokumen menjadi huruf kecil semua. Contoh isi yang dihapus adalah tag-tag HTML.
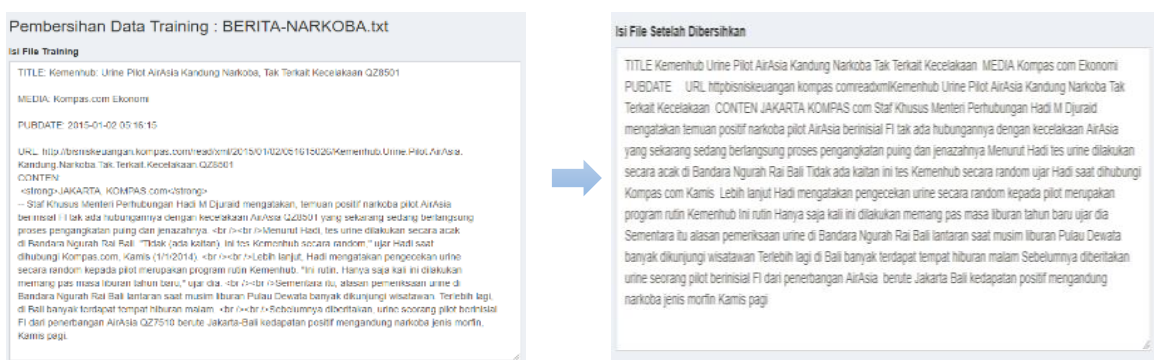

Gambar 2. Proses pembersihan data artikel berita daring

Preprocessing atau pra pemrosesan data adalah proses mengolah dan mengubah data mentah yang akan digunakan oleh sistem menjadi format yang sesuai. Tujuan utama dari proses pra pemrosesan adalah untuk mengekstrak informasi yang diperlukan dari suatu data. Tahapan pra pemrosesan terdiri dari proses tokenisasi, stemming, dan stopword (Hu \& Liu, 2012).

a. Tokenisasi

Proses tokenisasi yaitu memecahkan kalimat menjadi unit tunggal atau independen satu sama lain. Proses tokenisasi memisahkan kata berdasarkan karakter spasi, tab, dan baris baru. Tiap unit tunggal hasil dari proses tokenisasi disebut dengan token.

b. Stopwords

Proses stopwords adalah proses menghilangkan kata-kata yang sering muncul dan kata-kata yang tidak relevan dan tidak bermakna.

c. Stemming

Proses stemming adalah proses mentransformasi sebuah kata menjadi kata dasar. Terdapat dua algoritma untuk pendekatan proses stemming pada domain teks bahasa Indonesia. Algoritma yang pertama melakukan pendekatan confix stripping yang disertai dengan penelurusan dan pemindaian pada kamus. Algoritma yang kedua menggunakan pendekatan yang berbasis pada aturan (Parwita, 2015). 
Pada proses pra pemrosesan data akan mengekstrak dokumen berita daring untuk mendapatkan fitur-fitur kata yang akan digunakan pada proses berikutnya. Fitur-fitur kata yang didapatkan kemudian dilakukan pembobotan untuk dilakukan proses klasifikasi. Fitur kata yang didapatkan akan masuk ke proses pembobotan. Pembobotan yang dilakukan baik berupa pembobotan term frequency maupun TFIDF. Bobot yang dihasilkan akan masuk ke tahapan proses klasifikasi untuk mencari kelas yang diberikan pada dokumen uji. Hasil klasifikasi akan ditampilkan ke pengguna berupa nilai hasil perhitungan dan kelas yang ditentukan oleh sistem.

Pada Gambar 3 menjelaskan perubahan data saat pra pemrosesan data. Pra pemprosesan yang digunakan dalam penelitian ini antara lain:

a. Tokenisasi adalah pemecahan kalimt menjadi kata tunggal atau token.

b. Stopwords adalah menghapus kata-kata yang tidak bermakna untuk proses klasifikasi.

c. Stemming adalah proses mengubah kata yang berimbuhan menjadi kata dasar.
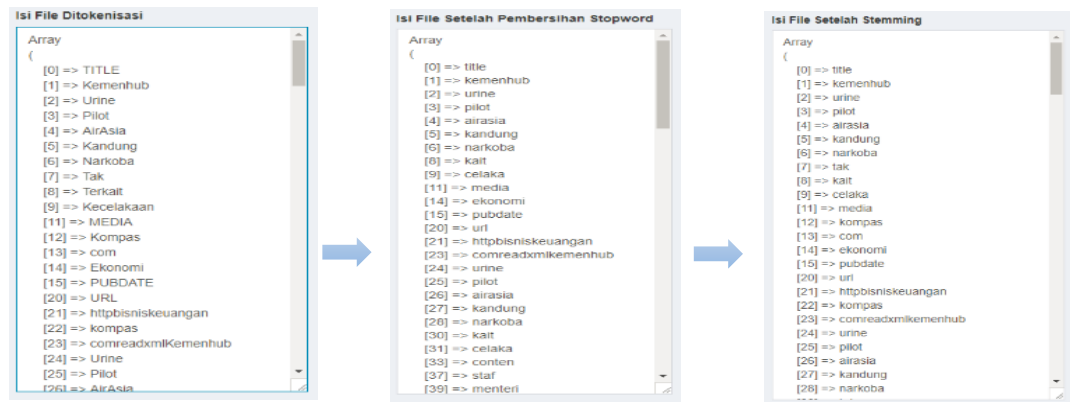

Gambar 3. Proses pra pemrosesan data artikel berita daring

User Interface (UI) aplikasi memiliki tiga bagian yaitu training, testing, dan confusion matrix. Bagian training digunakan untuk proses preprocessing dan menentukan kelas pada data berita daring yang ingin di crawler. Ada 2 cara yang bisa dilakukan untuk data training yaitu bisa upload file menggunakan format *.txt atau memasukkan url berita narkotika dari situs berita yang populer di Indonesia. Hasil implementasi halaman training diperlihatkan pada Gambar 4 dibawah ini: 


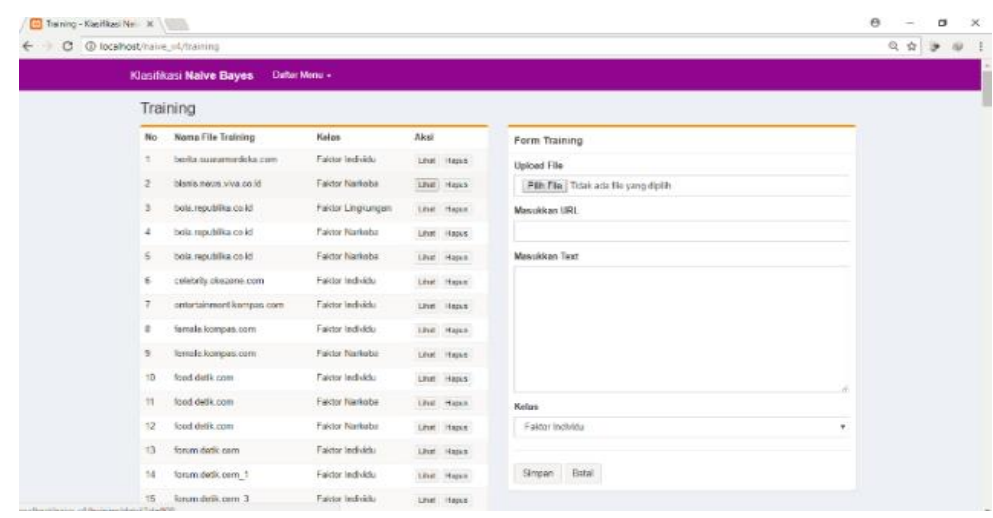

Gambar 4. Aplikasi training

Bagian testing digunakan untuk menguji data berita yang belum ada kelasnya. Untuk pengujiannya ada 2 cara yang bisa dilakukan untuk data testing yaitu bisa upload file menggunakan format *.txt atau memasukkan url berita narkotika dari situs berita yang populer di Indonesia. Ketika sudah memasukkan data testing maka sistem klasifikasi algoritma Naive Bayes yang akan melakukan proses klasifikasi data. Hasil implementasi halaman testing diperlihatkan pada Gambar 5 dibawah ini.

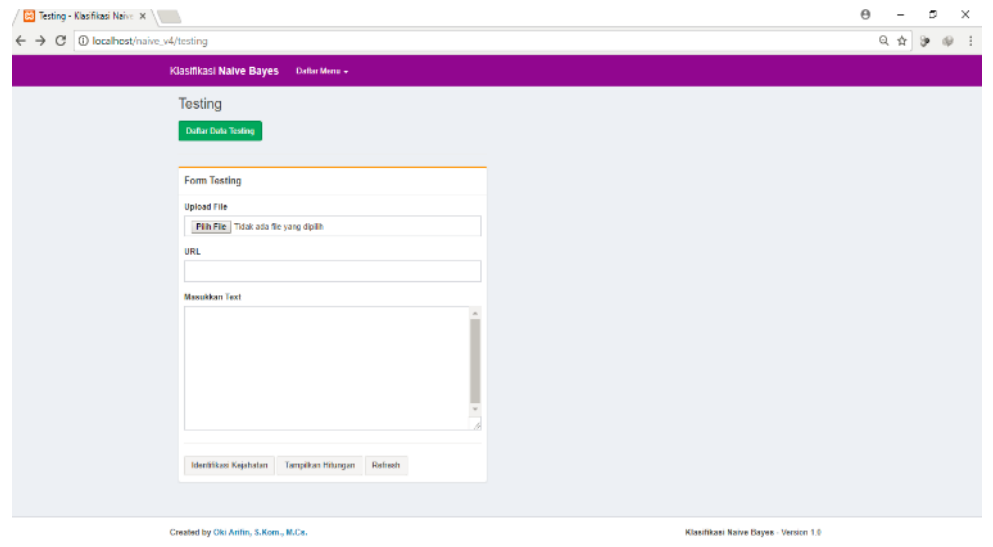

Gambar 5. Aplikasi testing

Bagian pengujian confusion matrix digunakan untuk menghitung akurasi sistem klasifikasi dari perhitungan recall, precision, dan accuracy. Untuk pengujian sistem ada 2 cara yang bisa dilakukan untuk data pengujian yaitu bisa upload file menggunakan format *.txt atau memasukkan url berita narkotika dari situs berita yang populer di Indonesia. Hasil implementasi halaman pengujian confusion matrix diperlihatkan pada Gambar 6 dibawah ini. 


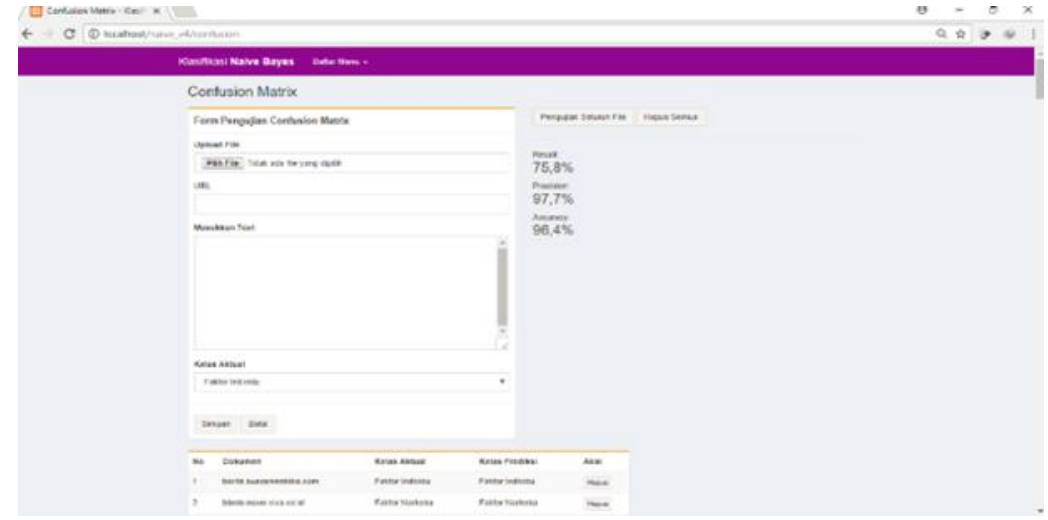

Gambar 6. Aplikasi pengujian confusion matrix

\section{HASIL DAN PEMBAHASAN}

Eksperimen dilakukan dengan menggunakan laptop Lenovo 20022 series dengan processor Intel Core 2 Duo @ 2,20 GHz $2.2 \mathrm{GHz}$, memory 2 GB, harddisk 320 GB, dan menggunakan sistem operasi Windows 10 Education 64bit. Eksperimen ini juga menggunakan library pendukung Sastrawi untuk proses stemming. Text editor yang digunakan Sublime Text 3, Xampp V322, MySQL, dan bahasa pemrograman PHP untuk pembuatan sistemnya. Metode yang digunakan adalah dengan menerapkan algoritma pengklasifikasi Naive Bayes (NB) untuk klasifikasi data artikel berita daring.

Data artikel berita daring yang digunakan sebagai data latih (training) disimpan di dalam database. Data berita daring tersebut telah diberikan label kelas sesuai pembelajaran pemahaman dari manusia terhadap faktor kejahatan penyalahgunaan narkotika. Pemberian label kelas dilakukan secara manual sesuai dengan kata kunci yang telah di tentukan. Berikut sebaran penggunaan data training untuk pembangunan sistem klasifikasi di perlihatkan pada Tabel 3 dibawah ini:

Tabel 3. Sample dataset untuk training

\begin{tabular}{|l|l|}
\hline \multicolumn{1}{|c|}{ Label Kelas } & Jumlah Data \\
\hline Faktor individu & 75 \\
\hline Faktor lingkungan & 75 \\
\hline Faktor narkoba & 75 \\
\hline Total data training & 225 \\
\hline
\end{tabular}


Pada Tabel 3 memperlihatkan total data training 225 data dari masingmasing kelas yaitu faktor individu dengan jumlah data 75, faktor lingkungan dengan jumlah data 75, faktor narkoba dengan jumlah data 75.

Pengujian akurasi dilakukan dengan menggunakan 225 data baru yang belum diketahui labelnya oleh sistem. Pengujian dilakukan dengan membandingkan antara kelas hasil prediksi klasifikasi dengan kelas sebenarnya (aktual) yang ditentukan oleh pengguna. Hasil pengujian performansi sistem menggunakan confusion matrix yang diperoleh di perlihatkan pada Tabel 4 dibawah ini:

Tabel 4. Performansi sistem menggunakan confusion matrix

\begin{tabular}{|l|c|l|l|}
\hline \multicolumn{4}{|c|}{ Confusion Matrix } \\
\hline Data Uji Baru & Recall & Precision & Accuracy \\
\hline 200 & $75,8 \%$ & $97,3 \%$ & $96 \%$ \\
\hline 225 & $75,8 \%$ & $97,7 \%$ & $96,4 \%$ \\
\hline
\end{tabular}

Dari Tabel 4 bisa di lihat bahwa performansi dari sistem yang dikembangkan menggunakan algoritma Naive Bayes dengan data uji 200 di dapatkan nilai recall 75,8 \%, precision 97,3\%, dan accuracy 96\%. Sedangkan dengan data uji 225 di dapatkan nilai recall 75,8 \%, precision 97,7\%, dan accuracy 96,4\%. Setelah dilakukan pengujian menggunakan algoritma Nä̈ve Bayes terhadap dua dataset, maka rata-rata (mean) hasil pengujian dapat dilihat pada Gambar 7 dibawah ini:

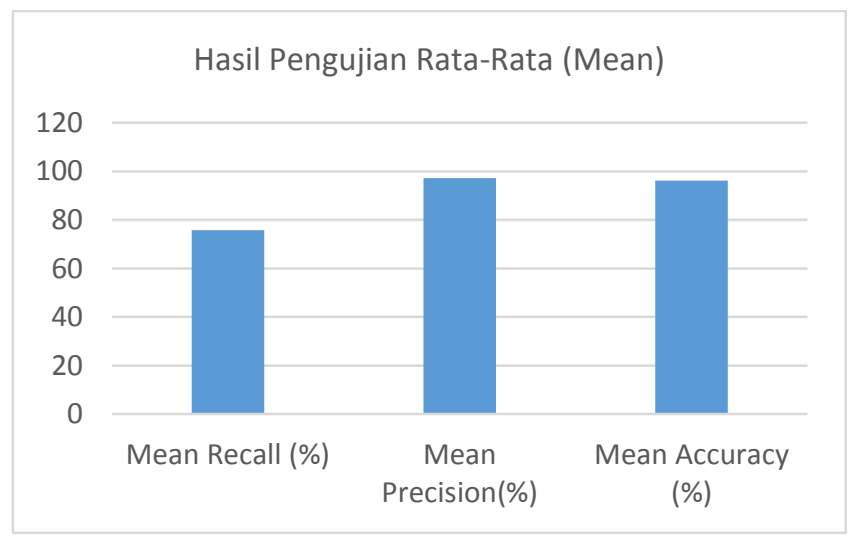

Gambar 7. Hasil rata-rata pengujian (mean) 
Pada Gambar 7 dapat di tarik kesimpulan bahwa algoritma Naive Bayes (NB) memiliki rata-rata pengujian meningkat dari 200 data uji ke 225 mempunyai akurasi yang baik karena mampu mencapai akurasi di atas $50 \%$.

\section{KESIMPULAN DAN SARAN}

Dari hasil penelitian dan pembahasan yang sudah dilakukan dapat ditarik kesimpulan sebagai berikut:

1. Penelitian ini berhasil membangun sebuah sistem yang mampu melakukan klasifikasi artikel berita daring faktor kejahatan penyalahgunaan narkotika menggunakan algoritma Naive Bayes (NB).

2. Berdasarkan hasil tingkat performansi sistem yang di bangun menggunakan confusion matrix dengan data uji 200 data baru di dapatkan nilai recall 75,8 $\%$, precision 97,3\%, dan accuracy 96\%. Sedangkan data uji 225 data baru di dapatkan nilai recall 75,8 \%, precision 97,7\%, dan accuracy 96,4\%. Dengan pengujian 2 dataset berbeda memiliki rata-rata akurasi sistem klasifikasi menggunakan Naive Bayes mempunyai tingkat akurasi yang baik karena tingkat akurasinya lebih dari $50 \%$.

Untuk pengembangan perangkat lunak ini masih memiliki keterbatasan yang dapat dijadikan acuan untuk pengembangan dimasa yang akan datang, sehingga disarankan beberapa hal yaitu:

1. Penelitian ini masih menggunakan library sastrawi untuk proses stemming. Untuk penelitian selanjutnya bisa mengembangkan proses stemming bahasa Indonesia agar lebih baik lagi.

2. Model sistem yang dibuat dengan algoritma klasifikasi Naive Bayes (NB), selanjutnya dapat dibandingkan dengan algoritma klasifikasi lainnya dari aspek akurasi model dan kecepatan waktu pemrosesannya.

\section{DAFTAR PUSTAKA}

Almanie, T., Mirza, R., \& Lor, E. (2015). Crime Prediction Based on Crime Types and Using Spatial and Temporal Criminal Hotspots. International Journal of Data Mining \& Knowledge Management Process, 5(4), 01-19. 
https://doi.org/10.5121/ijdkp.2015.5401

Candradewi, I. (2015). Pemrosesan Video Untuk Klasifikasi Jenis Kendaraan Menggunakan Algoritma Support Vector Machine. Universitas Gadjah Mada.

Darujati, C., Narotama, U., \& Darujati, C. (2016). Pemanfaatan Teknik Supervised Untuk Klasifikasi Teks Bahasa Indonesia, (February 2012).

Helviza, I., Mukmin, Z., \& Amirullah. (2016). Kendala-Kendala Badan Narkotika Nasional (Bnn) Dalam Penanggulangan Penyalahgunaan Narkotika Di Kota Banda Aceh. Screening, 11(1), 112-124.

Hu, X., \& Liu, H. (2012). Text Analytics in Social Media. London: Springer New York.

Jati Prabowo, S. (2015). Analisis Sinergi Antara Media Cetak Jawa Pos dan Media Online Jawapos.com. Universitas Gadjah Mada.

Junianto, E., \& Riana, D. (2017). Penerapan PSO Untuk Seleksi Fitur Pada Klasifikasi Dokumen Berita Menggunakan NBC. Ejournal.Bsi.Ac.Id, 4(1), $38-45$. Retrieved from http://ejournal.bsi.ac.id/ejurnal/index.php/ji/article/view/1810

Malarvizhi, R., \& Saraswathi, K. (2013). Web Content Mining Techniques Tools \& Algorithms - A Comprehensive Study. Web Content Mining Techniques Tools \& Algorithms - A Comprehensive Study, 4(8), 2940-2945. Retrieved from http://www.ijcttjournal.org

Muhamad, H., Prasojo, C. A., Sugianto, N. A., Surtiningsih, L., Cholissodin, I., Ilmu, F., ... Optimization, P. S. (2017). Optimasi Naive Bayes Classifier Dengan Menggunakan Particle Swarm Optimization pada Data Iris. Teknologi Informasi Dan Pendidikan, 4(3), 180-184.

Nurlila, R. U., \& La Fua, J. (2017). Penyalahgunaan Zat Adiktif pada Siswa Kelas VIII di Sekolah Menengah Pertama Negeri 05 Kota Kendari. Jurnal AlTa'dib, 10(1), 73-90.

Parwita, W. G. S. (2015). Hybrid Recommendation System Memanfaatkan Penggalian Frequent Itemset dan Perbandingan Keyword, 9(2), 19-21.

Pramudita, Y. D., Putro, S. S., Makhmud, N., Olahraga, B., Confix, E., \& Stemmer, S. (2018). Klasifikasi Berita Olahraga Menggunakan Metode Naïve Bayes Sports News Classification Using Naïve Bayes With Enhanced Confix Stripping Stemmer, 5(3). https://doi.org/10.25126/jtiik.201853810 
Vidya, S., \& Banumathy, K. (2015). Web Mining- Concepts and Application, 6(4), 3266-3268.

Wahyunita, L. (2016). Permodelan Klasifikasi Artikel Berita Online Penyebab Kasus Narkoba Menggunakan Algoritma Roccio. Universitas Gadjah Mada. 